\title{
Marble quarrying: an energy and waste intensive activity in the production of building materials
}

\author{
V. Liguori ${ }^{1}$, G. Rizzo $^{2} \&$ M. Traverso ${ }^{2}$ \\ ${ }^{1}$ Dipartimento di Ingegneria Strutturale e Geotecnica, \\ Università degli Sudi di Palermo, Viale delle Scienze, Palermo Italy \\ ${ }^{2}$ Dipartimento di Ricerche Energetiche ed Ambientali, \\ Università degli Studi di Palermo, Viale delle Scienze, Palermo, Italy
}

\begin{abstract}
Marble represents an important component of Italian buildings, where it is often utilized as a covering for bottom surfaces, despite its relatively high price. Moreover, it characterizes several public buildings, for which it is by far the most important decorative material, also because of its structural features and its long durability. Unfortunately, marble quarrying is an energy intensive activity that requires relevant amounts of electric and thermal energy sources; in addition, the extraction of the marble blocks from the mountain sides does involve a noticeable quantity of explosives, particularly in sites where traditional working methods are utilized. Another important feature of the marble mining is represented by the high level of waste materials released during the quarrying process. Both these elements call for careful attention to the production of this material, aiming for a suitable reduction of the environmental impact exerted by the current working procedures. An energy audit analysis, moreover, could allow the singling out of the steps of the whole process where it would be possible to reach improved efficiency, in this way properly cutting the energy resources involved in the production of the functional unit of this natural stone. The feasibility of such considerations is verified by means of an application to a marble quarry in Sicily, the region where an important rate of the Italian domestic production is realized. The field energy audit, other than suggesting a general approach to the problem, does indicate the high inefficiencies actually present in the working chain of the Sicilian marble.
\end{abstract}

Keywords: marble, life cycle assessment, energy and environmental audits, embodied energy, eco-indictors. 


\section{Introduction}

The building sector plays a meaningful role in energy consumption and environmental impacts. This sector is often defined the " $40 \%$ sector" [1], since its accounts for about $40 \%$ of the whole energy consumption. For this reason it is important to adopt good policies and procedures for reducing the environmental impact of this particular sector. In this field, Life Cycle Assessment (LCA) established a strategic role for planning, monitoring and control of both energy and environment fallouts.

Marble production is one of the most important sectors in Italy and in particular in Sicily. In Italy its whole production accounts for $18 \%$ of world output; Carrara, a province of Tuscany, and Custonaci, a municipality of Trapani province (Sicily), plays the most meaningful role in marble tile production [2]. In fact, 190 quarries are located in Carrara and 54 in Custonaci.

In normal operative conditions, the main impacts can come from air emissions, the sludge and the large amount of scraps.

This work intends to present some results of a LCA application in marble cycle production and to make a comparison between two of the most important marble producers in the selected areas: Perlato di Sicilia and Bianco Carrara.

\section{Marble and its production}

Marble is a limestone or dolomite stone which is sufficiently close in texture to permit it being polished. Many other ornamental stones - such as serpentine, alabaster and even granite - are sometimes designated as marble, despite the term it should be invariably restricted to those crystalline and compact varieties of carbonate of lime (occasionally with carbonate of magnesia) which, when polished, are applicable to purposes of decoration [3].

Right now the definition is even more general and includes, under the concept of marble, all ornamental stones. The use of marble goes back several centuries. It is common to find several examples of marble in old churches, buildings and other important historical monuments.

Up till the XVI century, the techniques used for extraction of marble had been directly inherited by the Roman quarrymen of the first century, before Christ, and consisted of the careful use of the subtle cracks which divide the different layers of marble. All work was carried out by slaves where, by using metallic chisels and wooden wedges which were inflated by water, were then placed inside the natural cracks and easily managed to separate the marble blocks from the mountain. This was possible because there was a large amount of available labour and unskilled workers.

With the arrival of explosives, the excavation procedures changed drastically and the Apennine landscape went through a profound change and several "ravaneti" appeared everywhere. They were formed by large build-ups of debris, which were witness to the large waste of marble products due to the explosions. 
Step-by-step the industrial activity relating to marble extraction and processing begun, with important factories established for the cutting and polishing of slabs. These productive units concentrated themselves at the bottom of valleys in order to benefit from the hydraulic energy generated by the rivers.

Since the end of the XIX century the helicoidally wire, a metallic cable able to dig out the stone, substituted almost completely explosives and caused another visible change in the landscape. The mountain stopped being destroyed, leaving behind piles of wreckage, and begun to be literally "cut", sculpted with precision, creating surreal landscapes made of huge flights of steps, and platforms called quarry warehouses where the stone is cut and prepared for transport.

Today the production is more technological and its life cycle mainly includes (figure 1) [4] the extraction in the quarry, the finishing treatment such as smoothing, polishing and finishing and the transportation and sale activities.

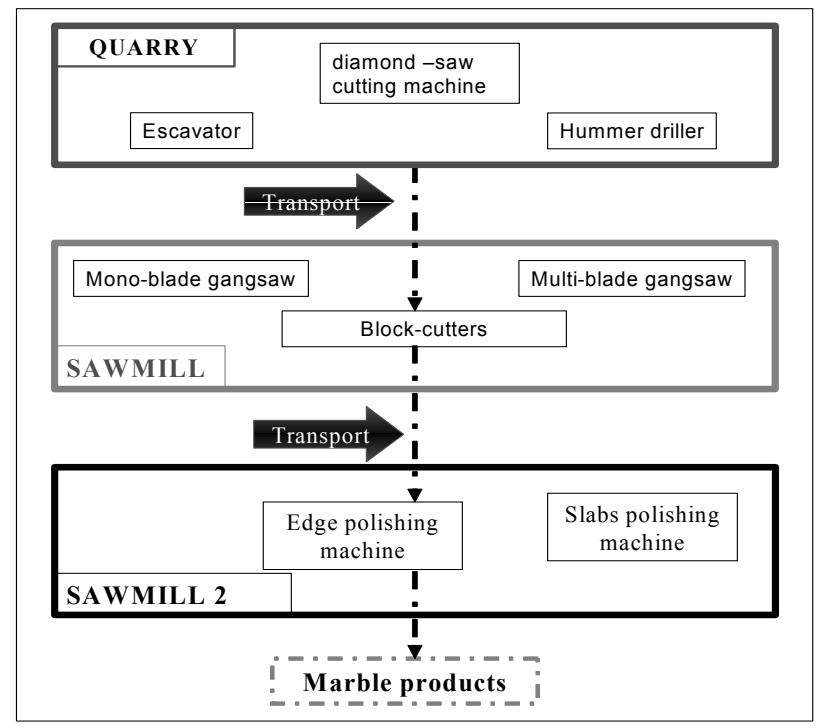

Figure 1: Flow chart of marble production.

\section{Custonaci and Carrara marble basins}

The extraction activity in Carrara goes back to Roman times. Indeed, the extraction of Custonaci marble started around 1950-51, mainly to cover local demand for white Carrara marble, which was becoming difficult and costly to supply. Anyway, in the Custonaci and Carrara marble fields, a wide amount of marble products are currently extracted (figure 2 ). 
There are three important marble fields in Massa Carrara [5], the Torano basin, Fatiscritti basin and Colonnata basin.

The first one is a western marble basin, consisting of thirty-one quarries with a total production amount of about 27,000 tons/month. The quarried marbles are amongst the most valuable ones: Statuario, Statuario Venato and Calacata. The Fantiscritti basin consists of thirty quarries and produces more than 30,000 tons/month of marble products. The main products are: Bianco Ordinario and Venato. The Colonnata basin constitutes the eastern part of the Carrara marble region and holds about seventy quarries, 44 of which are still active, on a total surface of 500 hectares.

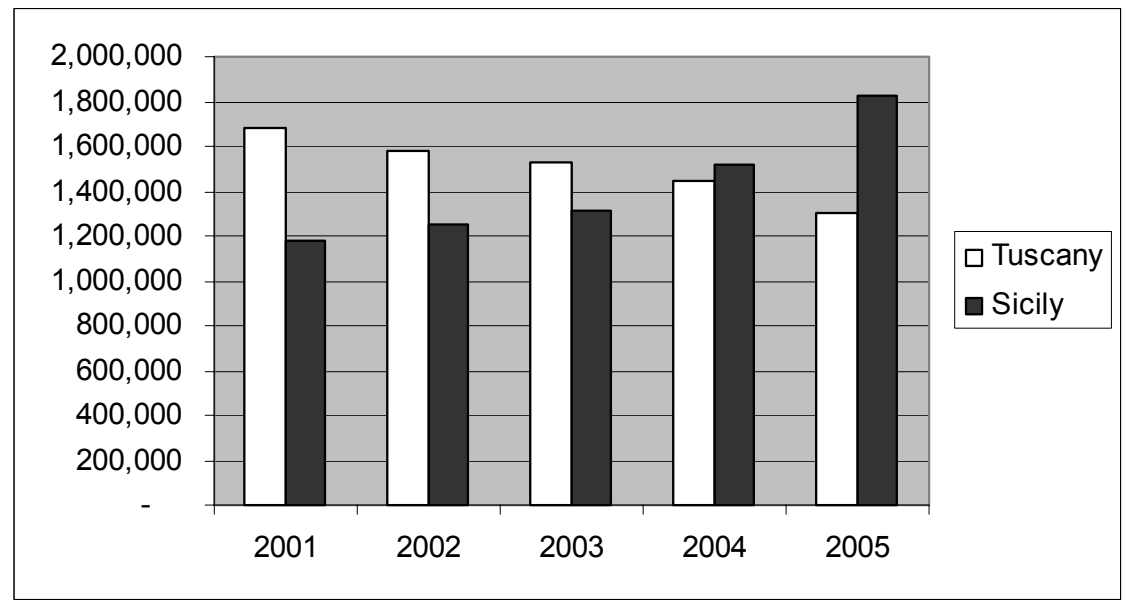

Figure 2: Comparison of marble production of Tuscany and Sicily.

The Carrara marble is made by metamorphic rocks consisting of $98 \%$ calcite and $2 \%$ dolomite, apatite, illite, goethite and quartz. They were originated from several phenomena of deterioration, compression, erosion, entrainment and deposit of detritus from pre-existent rocks and/or animal and vegetable remains in marine habitat.

The importance of this district is underlined by the current Italian standard that defines the Carrara Marble where it describes in details all characteristics that the marble has to have for being defined "Carrara Marble".

Also Sicily plays an important role in marble production in Italy. The various kinds of marble extracted in Sicily are shown in Table 1, with their main physics and geological characteristics.

Custonaci basin is consisting of about 54 marble quarries in a small area of 69 $\mathrm{km}^{2}$. Due to its geological conformation, characterized by extensive outcrops of limestones of Mesozoic Dolomitic limestones, the territory of Custonaci is characterized by wide deposits of precious stone materials that have been exploited for fifty years and have contributed to the creation of a landscape marked by human presence where the dominant features are quarries. Presently, 
the Custonaci industrial area produces 1,800,000 tons/year that represents about $85 \%$ of marble in Sicily; it is equivalent to $15.7 \%$ in Italy and $2.7 \%$ in the world.

Only $25 \%$ of this material is used commercially, while the remaining $75 \%$ is constituted by waste of production.

Table 2 shows a comparison between characteristic data of two of the most important types of marble, that is Perlato di Sicilia (Custonaci basin) and Bianco Carrara (Carrara basin) [6].

Table 1: Kinds of marbles extracted in Sicily.

\begin{tabular}{|c|c|c|c|c|c|c|c|}
\hline Name & $\begin{array}{c}\text { Material } \\
\text { kinds }\end{array}$ & Mining area & Manifacturing & $\begin{array}{c}\text { Specific } \\
\text { Weight (SW) } \\
{\left[\mathrm{g} / \mathrm{cm}^{3}\right]}\end{array}$ & $\begin{array}{c}\text { Resistance to } \\
\text { compression } \\
\text { (RC) }\left[\mathrm{kg} / \mathrm{cm}^{2}\right]\end{array}$ & $\begin{array}{c}\text { Absorption } \\
{[\%]}\end{array}$ & $\begin{array}{c}\text { Compressive } \\
\text { Strength after } \\
\text { gelivity }\left[\mathrm{kg} / \mathrm{cm}^{2}\right]\end{array}$ \\
\hline Avorio Venato di Custonaci & limestone & Custonaci (TP) & $\begin{array}{c}\begin{array}{c}\text { smoothing and } \\
\text { polishing }\end{array} \\
\end{array}$ & 2.65 & 1,290 & 0.28 & 1,140 \\
\hline Pietra Lavica & basalt & Etna. Catania & $\begin{array}{c}\begin{array}{c}\text { smoothing and } \\
\text { polishing }\end{array} \\
\end{array}$ & 2.83 & 109 & 0.16 & 108 \\
\hline Granitello & limestone & Piana & polishing & 2.68 & 1,230 & 0.26 & 1,215 \\
\hline Perlato di Sicilia & limestone & Custonaci (TP) & $\begin{array}{c}\text { smoothing. } \\
\text { polishing and } \\
\text { bushammering } \\
\text { finish } \\
\end{array}$ & 2.68 & 1,250 & 0.32 & 1,045 \\
\hline Pietra Sabucina & Calcarenite & Sabucina (CL) & $\begin{array}{c}\text { Columns and } \\
\text { capitals }\end{array}$ & 1.33 & 130 & 7.5 & 92 \\
\hline Rosso Bolognetta & limestone & Bolognetta (PA) & $\begin{array}{c}\text { smoothing. } \\
\text { polishing and } \\
\text { bushammering } \\
\text { finish }\end{array}$ & 2.67 & 1,215 & 0.36 & 1,087 \\
\hline Botticino Venato & limestone & Custoanci (TP) & smoothing & & & & \\
\hline Grigio Mirto & limestone & San Marco D'Alunzio (ME) & $\begin{array}{c}\text { smoothing. } \\
\text { polishing and } \\
\text { bushammering } \\
\text { finish } \\
\end{array}$ & 2.69 & 1,085 & 0.12 & 925 \\
\hline Pietra Pece di Ragusa & $\begin{array}{c}\text { Asphalt } \\
\text { Stone }\end{array}$ & Ragusa & $\begin{array}{c}\begin{array}{c}\text { smoothing and } \\
\text { polishing }\end{array} \\
\end{array}$ & 2.18 & 133 & 2.74 & 128 \\
\hline $\begin{array}{l}\text { Rosso San Marco - Rosso } \\
\text { antico di Sicilia }\end{array}$ & limestone & San Marco D'Alunzio (ME) & $\begin{array}{c}\text { smoothing. } \\
\text { polishing and } \\
\text { bushammering } \\
\text { finish } \\
\end{array}$ & 2.67 & 1,335 & 0.16 & 1,268 \\
\hline Grigio San Marco & limestone & San Marco D'Alunzio (ME) & $\begin{array}{c}\text { smoothing. } \\
\text { polishing and } \\
\text { bushammering } \\
\text { finish }\end{array}$ & 2.68 & 1,220 & 0.11 & 1,036 \\
\hline $\begin{array}{c}\text { Arenaria grigia dei Nebrodi o } \\
\text { Quarzarenite }\end{array}$ & $\begin{array}{c}\text { Quarzarenit } \\
\mathrm{e}\end{array}$ & Nebrodi & $\begin{array}{c}\begin{array}{c}\text { smoothing and } \\
\text { polishing }\end{array} \\
\end{array}$ & 2.6 & 1,040 & 1.82 & 887 \\
\hline Grigio San Marco & limestone & Messina & $\begin{array}{c}\text { smoothing. } \\
\text { polishing and } \\
\text { bushammering } \\
\text { finish }\end{array}$ & 2.68 & 1,220 & 0.11 & 1,036 \\
\hline Pietra di Cosimo & & Comiso & $\begin{array}{c}\begin{array}{c}\text { smoothing and } \\
\text { polishing }\end{array} \\
\end{array}$ & 2.81 & 1,320 & 0.93 & 1,060 \\
\hline Perlatino di Sicilia & limestone & Custonaci (TP) & $\begin{array}{c}\text { smoothing. } \\
\text { polishing and } \\
\text { bushammering } \\
\text { finish }\end{array}$ & 2.67 & 1,280 & 0.31 & 1,070 \\
\hline Grigio di Billiemi & $\begin{array}{c}\text { Calcareous } \\
\text { breccia }\end{array}$ & Palermo & $\begin{array}{c}\text { smoothing. } \\
\text { polishing and } \\
\text { bushammering } \\
\text { finish } \\
\end{array}$ & 2.7 & 1,430 & 0.12 & 1,226 \\
\hline Label Cream & limestone & Bolognetta (PA) & $\begin{array}{c}\text { smoothing. } \\
\text { polishing and } \\
\text { bushammering } \\
\text { finish }\end{array}$ & 2.61 & 1,280 & 0.34 & 1,083 \\
\hline Nerello di Custonaci & limestone & Custonaci (TP) & $\begin{array}{c}\text { smoothing. } \\
\text { polishing and } \\
\text { bushammering } \\
\text { finish }\end{array}$ & 2.61 & 1,088 & 0.21 & 984 \\
\hline Botticino di Sicilia & limestone & Custonaci (TP) & \begin{tabular}{|c|} 
smoothing. \\
polishing and \\
bushammering \\
finish
\end{tabular} & 2.66 & 1,180 & 0.34 & 1,040 \\
\hline
\end{tabular}


Table 2: $\quad$ Comparison of Custonaci and Carrara Marbles.

\begin{tabular}{|l|l|l|l|l|l|l|l|}
\hline Name & Description & $\begin{array}{c}\text { Specific } \\
\text { weight } \\
(\mathrm{SW}) \\
\left.\left[\mathrm{g} / \mathrm{cm}^{3}\right)\right]\end{array}$ & $\begin{array}{c}\text { Resistence } \\
\text { to } \\
\text { compressio } \\
\mathrm{n} \\
(\mathrm{RC}) \\
{\left[\mathrm{kg} / \mathrm{cm}^{2}\right]}\end{array}$ & $\begin{array}{c}\text { Compression } \\
\text { strength after } \\
\text { gelivity } \\
{\left[\mathrm{kg}^{2} / \mathrm{cm}^{2}\right]}\end{array}$ & $\begin{array}{c}\text { Water } \\
\text { absorp. } \\
\text { tion } \\
\text { coeff. } \\
{[\%]}\end{array}$ & $\begin{array}{c}\text { Impact } \\
\text { resistance } \\
{[\mathrm{cm}]}\end{array}$ & $\begin{array}{l}\text { Frictional } \\
\text { wear } \\
\text { coefficient }\end{array}$ \\
\hline $\begin{array}{l}\text { Perlato } \\
\mathrm{di} \\
\text { Sicilia }\end{array}$ & $\begin{array}{l}\text { Cretacious calcareous, it's light } \\
\text { ivory in colour with brown } \\
\text { arabesques with darker or lighter } \\
\text { shades and beautiful pure calcite } \\
\text { streaks that recall the mother of } \\
\text { pearl inside of shells. Suitable for } \\
\text { any indoor or outdoor application } \\
\text { in modern building and also in } \\
\text { urban furnishing. }\end{array}$ & 2.68 & 1,250 & 1,045 & 0.32 & 29 & 0.57 \\
\hline $\begin{array}{l}\text { Bianco } \\
\text { Carrarara }\end{array}$ & $\begin{array}{l}\text { Bianco Carrara "D" is a marble } \\
\text { quarried in Carrara's area. It has } \\
\text { grey background and dark grey } \\
\text { veins. The quality is determined } \\
\text { by the absence of large grey-black } \\
\text { veins and quartzite } \\
\text { concentrations. Suitable for any } \\
\text { indoor and outdoor application } \\
\text { and also for urban furnishing. }\end{array}$ & 2.71 & 1,334 & 1,300 & 0.12 & 56 & 0.58 \\
\hline
\end{tabular}

\section{Energy and environmental audit of Custonaci marble}

As has been previously pointed out, marble production has a very important landscape and environmental impact, particularly during the extraction and cutting steps. Where the marble quarry has a really large dimensions and usually where the geology characteristics of land allows to extract marble, there are several quarries in a small area. This can cause several environment problems, such as: disposal of scraps and sludge, along with air pollutant emissions. Generally speaking, during the extraction phase, the remarkable production of the so called "ravaneti", that is the scraps produced during the quarry operations, represent by far the most important wastes. On the other hand, the cutting and polishing phases produce a large amount of slush, that are essentially constituted by a mix of marble dusts with the cooling water utilized in the working process; the solid part of this mix is called "marmettola" that, sometimes, can be usefully addressed toward the employment in the building and civil sector.

The energy audit carried out in this work is particular important because it involves one of the most productive and impacting activity sector in Sicily.

In a context of energy saving and reduction of $\mathrm{CO}_{2}$ emissions, the proper understanding of the amount of these impacts does represent a strategic move for reaching the fixed environmental targets of the European Union.

The adopted impact assessment methodology is the so-called "problemoriented" [7] in which, as stated by the ISO series 14040 [8], the inventory data are associated with specific environmental impact categories, in order to better understand those impacts. The result of the energy audit is shown in figure 3. 
The contribution of the energy utilized for explosive purposes is very small in comparison with the other compounds, but it has to be suitably considered because of its environmental impacts.

The most relevant energy impact is produced by sawmills, where the marble is cut and treated to be transformed into slabs and tiles.

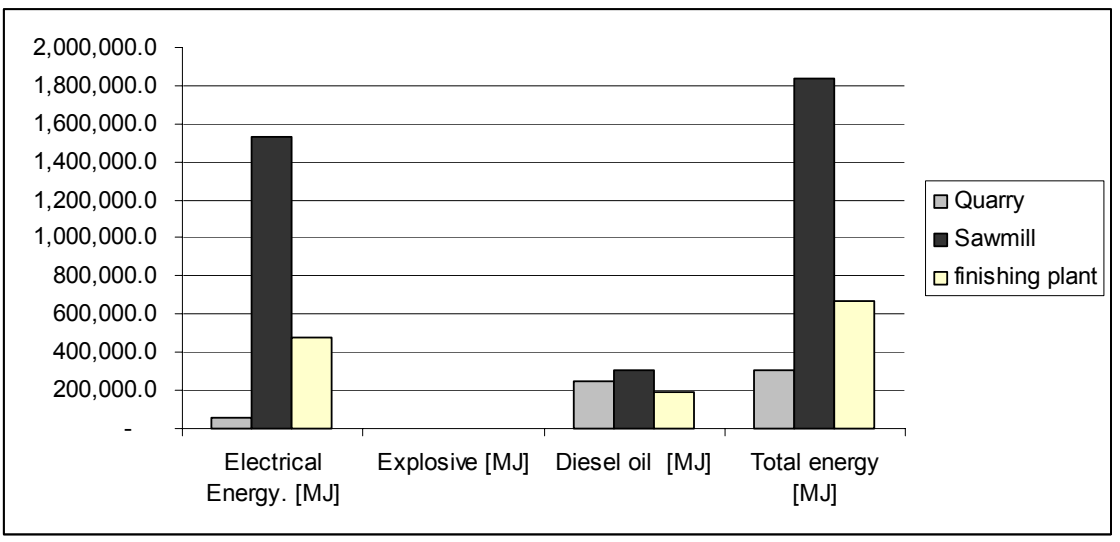

Figure 3: $\quad$ Energy inputs of marble production in the examined site.



Figure 4: $\quad$ Main wastes from marble production in the examined site.

The result of total produced scraps is shown in figure 4. The quarry scraps, the so-called "spoil", are obtained using the explosives for moving the cut blocks from the mountain. This operation is necessary for allowing workers to transform the almost shapeless mass of stone into squared or semi-squared blocks, with standard dimensions. In fact, it is not possible to control the explosion very well that is used to move the big blocks from the rest of the mountain (since it depends on the characteristics of the deposit); so it often 
causes a big amount of spoil which is transferred directly toward a dedicated landfill.

Other inputs, such as water and resins, along with their amounts are reported in table 3 .

Table 3: $\quad$ Other material inputs of marble production.

\begin{tabular}{|c|c|}
\hline & $\begin{array}{c}\text { Marble-chip floor tiles \& } \\
\text { slabs }\end{array}$ \\
\hline Water in quarry $\left[\mathbf{m}^{\mathbf{3}} / \mathbf{m}^{\mathbf{3}}\right]$ & 0.21 \\
\hline Water in sawmill $\mathbf{1}\left[\mathbf{m}^{\mathbf{3}} / \mathbf{m}^{\mathbf{3}}\right]$ & 0.12 \\
\hline Resin $\left[\mathbf{K g} / \mathbf{m}^{3}\right]$ & 3.99 \\
\hline Floculating $\left[\mathrm{Kg} / \mathbf{m}^{3}\right]$ & 0.19 \\
\hline
\end{tabular}

These inputs are related with the production of slabs and tiles: they are referred to by the cubic meter of slabs and tiles produced, that is assumed as the functional unit of marble $\left(1 \mathrm{~m}^{3}\right)$. The larger part of the water comes from private draw water and is recycled by a depurator, sited in the sawmill. The flocculating is a chemical compound, utilized for clarifying waste water and flocculating the sludge. Then the sludge is filtered by a filter-press.

The resin is used to improve the resistance of slabs and tiles before the finishing treatment takes place.

Greenhouses gasses produced, here referred to $\mathrm{CO}_{2}$ emissions, are reported in figure 5. It is interesting to observe that the amount of $\mathrm{CO}_{2}$ emissions is two orders of magnitude bigger than the other released pollutants.



Figure 5: Pollutant emissions from the marble production in the site. 


\section{Results}

The environmental impacts which have been taken into account in this study are energy consumption, water effluents, soil and air emissions and resources consumption. All results are reported in terms of functional unit $\left(\mathrm{m}^{3}\right)$ of products in order to allow a comparison with similar international and national data. Main products in the plant analyzed are slabs and cheap-floor tiles.

The index here adopted to compare the result of energy consumption with other building products is the embodied energy (EE) [9]. It is defined as the energy consumed by all of processes associated with the production of a building material, from the acquisition of natural resources to product delivery. The results of this work are reported in figure 6. It is evident that marble tiles are more expensive in terms of energy than slabs, while the biggest share of energy is attributable to the electrical energy. The energy for explosive is very small in comparison with the other two compounds but its use produces a remarkable amount of soil spoil.

The last part of the environmental audit procedure refers to the effects of the environmental emissions into some relevant damage categories [10], that allow the evaluation of the environmental impacts by three different points of view:

- Human Health

- Ecosystem Quality

- Resources

The results for the Perlato di Sicilia are shown in the figure 7: the biggest impact of functional unit of marble of Custonaci $\left[\mathrm{m}^{3}\right]$ is on the Ecosystem Quality category. This means that the impact is not directly related to the human beings but it can seriously compromise the natural ecosystems and can contribute to the climate change.

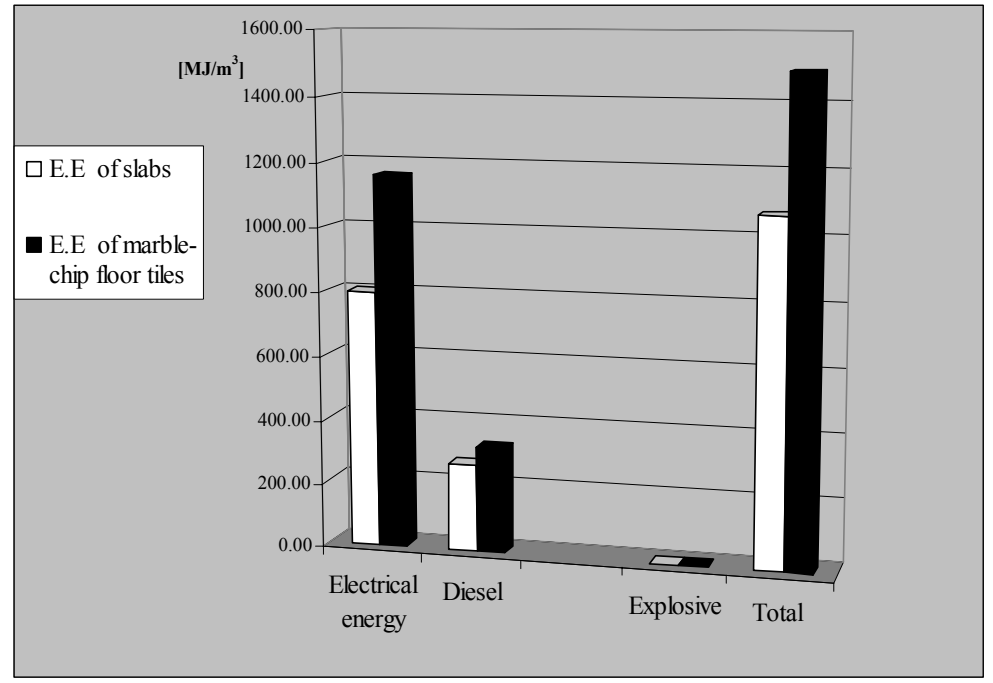

Figure 6: Embodied energy (EE) of the marble production in the site. 




Figure 7: $\quad$ Eco indicator results of marble tiles and slabs.

\section{Conclusions}

The study presented in this work has reported the energy and environmental audits of marble slabs and tiles produced in the Custonaci basin, along with a simple comparison with that produced in Carrara. In fact, it represents an important national problem in Italy which is why it is really important in singling out the weak points of marble's production cycle in terms of energy and environmental efficiency.

The results indicate that the use of explosives is not so meaningful for air emissions but it causes a large amount of solid waste. A comparison with the Carrara marble production suggests a solution, by substituting the explosive with straddle bearing in order to achieve more control in the moving operations of marble blocks.

Moreover, the biggest environmental impact regarding air emissions is carbon dioxide, that is a relevant pollutant component for the ecosystem stability and for climate change. The biggest share of emissions, as shown in figure 3, come from electrical energy consumption, so a good solution for compensating the $\mathrm{CO}_{2}$ emissions could be the installation of photovoltaic panels in the plants for producing electric energy from renewable sources. At present, access to these kind of technologies is made interesting thanks to several incentive measures introduced by the Italian national government in order to accomplish the main goals of the Kyoto Protocol.

Of course, the one presented here must be regarded as a first application and it surely needs other audits in the field with the aim of confirming these results. Anyway, since it represents the first experimental approach in the Sicilian productive context of marble, it can be usefully adopted for evaluating the environmental impact of such important components of the marble production, that is the "Perlato di Sicilia". 


\section{References}

[1] CAN Europe. Input from environmental NGOs at the start of next round of the European Climate Change Program (ECCP), Climate Action Network Brussels, 24 ${ }^{\text {th }}$ October 2005.

[2] Nicoletti G.M., Notarnicola B. and Tassielli G. Comparative Life Cycle Assessment of flooring materials: ceramic versus marble tiles, Journal of Cleaner Production N. 10 2002, pp. 283-296, Elsevier, 2002.

[3] UNI EN 12670:2003, Natural Stone: terminology.

[4] La Gennusa M., Raimondi C., Rizzo G., Traverso M. Environmental impact of marble mining: the case study of a Sicilian marble quarry. Proceedings of SETAC Europe - 13th LCA Case Studies Symposium. Stuttgart, Germany, 7-8 December 2006.

[5] Bradley F. Le Cave di Marmo di Carrara. Guida ai materiali e produttori Studio Marmo, Imm Carrara, pp. 110, 1998.

[6] Pieri M. Marmologia. Dizionario di marmi, graniti Italiani ed Esteri, Hoepli editore, Milano, 1966.

[7] Heijungs R. Environmental life cycle assessment of products: guide and backgrounds, Leiden University, the Netherlands. Center for Environmental Science; (CLM), Leiden University, the Netherlands, 1992.

[8] ISO, International Organization for Standardization. ISO/DIS 14040: Environmental management - Life Cycle Assessment — Principles and framework. 1997.

[9] Lenzen M. and Treloar G.J. Embodied energy in buildings: wood versus concrete, reply to Börjesson and Gustavsson, Energy Policy, Vol 30, pp. 249-244, 2002.

[10] AAVV,. The Eco-Indicator 99: A damage oriented method for Life Cycle Impact Assessment. PRè Consultants B.V., 2000. 